Między wykluczeniem a dobrobytem. Refleksja nad społeczna myślą encykliki „Centesimus annus” Jana Pawła II, red. B. Bąk,

R. Kantor, M. Kluz, J. Młyński, Kraków 2017, s. 35-51.

DOI: http://dx.doi.org/10.15633/9788374386289.03

Ks. dr Wiesław Pieja

Proboszcz parafii Okocim

\title{
Oblicza agnostycyzmu, ateizmu, laicyzacji i sekularyzacji a poszanowanie transcendencji osoby godności ludzkiej w Centesimus annus
}

Enyklika Centesimus annus jest podsumowaniem katolickiej nauki społecznej Kościoła. Ojciec Święty Jan Paweł II, analizując w niej poszczególne nurty filozoficzno-społeczne, daje wspaniały wykład podsumowujący katolicką naukę Sspołeczną, w której mocno podkreśla podmiotowość człowieka i jego godność w strukturze życia społecznego ${ }^{1}$. Człowiek ma obowiązek szukać prawdy o sobie, o świecie, o osobowym Bogu, a gdy te zasady pomija, powstają nurty filozoficzne negujące Boga i człowieka, takie jak: agnostycyzm, ateizm, laicyzacja, sekularyzacja, różnego rodzaju zakamuflowane totalitaryzmy. Doprowadzają one do tego, że uważa się człowieka za „absolutne centrum rzeczywistości, każąc mu w ten sposób wbrew naturze rzeczy zająć miejsce Boga, zapominając o tym, że to nie człowiek czyni Boga, ale Bóg czyni człowieka. Zapomnienie o Bogu doprowadziło 
do porzucenia człowieka” i dlatego „nie należy się dziwić, jeśli w tym kontekście otworzyła się rozległa przestrzeń dla swobodnego rozwoju nihilizmu na polu filozofii, relatywizmu na polu teorii poznania i moralności, pragmatyzmu i nawet cynicznego hedonizmu w strukturze życia codziennego. Europejska kultura sprawia wrażenie milczącej apostazji człowieka sytego, który żyje tak, jakby Bóg nie istniał"2.

Dzisiaj zwykło się twierdzić, że filozofią i podstawą odpowiadającą demokratycznym formom polityki są agnostycyzm i sceptyczny relatywizm. Politycy zaś żywią przekonanie, że prawda zmienia się wraz ze zmienną równowagą polityczną. W sytuacji, w której nie istnieje żadna ostateczna prawda, będąca przewodnikiem w działalności politycznej i nadająca jej kierunek, łatwo o instrumentalizację idei i przekonań, wykorzystywanie ich do celów, jakie stawia sobie władza. Historia uczy, że demokracja bez wartości łatwo przemienia się w jawny lub zakamuflowany totalitaryzm.

Jednak Kościół nie zamyka bynajmniej oczu na niebezpieczeństwo fanatyzmu czy fundamentalizmu tych ludzi, którzy w imię ideologii uważającej się za naukową albo religijną czują się uprawnieni do narzucania innym własnej koncepcji prawdy i dobra. Prawda chrześcijańska do tej kategorii nie należy. Wiara chrześcijańska, która nie jest ideologią, nie twierdzi, by mogła ująć w sztywny schemat bardzo różnorodną rzeczywistość społeczno-polityczną, i uznaje, że życie ludzkie w historii realizuje się na różne sposoby, które bynajmniej nie są doskonałe. Tak więc stanowiskiem Kościoła jest poszanowanie wolności przy niezmiennym uznawaniu transcendentalnej godności osoby ludzkiej ${ }^{3}$. Człowiek jest sobą przez prawdę i staje się bardziej sobą przez coraz pełniejsze poznawanie prawdy ${ }^{4}$.

2 Jan Paweł II, Posynodalna adhortacja apostolska Ecclesia in Europa, 9.

3 Jan Paweł II, Encyklika Centesimus annus, 47.

4 Jan Paweł II, Przyszłość człowieka zależy od kultury. Przemówienie wygłoszone 2 czerwca 1980 roku w UNESCO, 17, www.wiez.pl/laboratorium/teksty.php?przyszlosc_czlowieka_zalezy_od_kultury_przemowieni\&p=8 (4.08.2017). 
Prawda, jako zgodność ludzkiego poznania z obiektywnie istniejącą rzeczywistością, czyli z prawdą (racjonalnością) rzeczy i osób a więc prawda w sensie klasycznego realizmu - jest podstawową wartością człowieka. Rozumność człowieka czyni go zdolnym do odczytania prawdy o otaczającym go świecie, a przede wszystkim prawdy o sobie samym - kim jest, skąd pochodzi i dokąd zmierza, czyli tego, jakie są źródła jego istnienia i sens życia ${ }^{5}$.

Życie człowieka, jego rozwój indywidualny i społeczny nie jest możliwy bez poszanowania naturalnego i pierwotnego prawa do poznania prawdy i kierowania się nią w życiu. Człowiek posiada nie tylko prawo, lecz także obowiązek szukania prawdy o sobie, jak również spojrzenia na całą rzeczywistość (światopogląd) i znalezienia w niej swego miejsca. Według realizmu człowiek poznaje prawdę, czyli odczytuje ją w obiektywnie istniejącej rzeczywistości, która jest racjonalna, to znaczy poznawalna, i powinien kierować się nią w swoim działaniu. W odpowiedzi na to stanowisko pojawiły się nurty filozoficzne, które nie uznają racjonalności rzeczywistości i przyjmują, że prawda powstaje w wyniku pewnych działań ludzkich. Jednym $\mathrm{z}$ tych nurtów wymienianych w encyklice Centesimus annus jest agnostycyzm.

Termin ten pochodzi od greckiego słowa agnostos, co dosłownie oznacza „niepoznawalny”, i wyraża stanowisko filozoficzne i teologiczne wykluczające możliwość poznania absolutu (Boga), ograniczające możliwości poznawcze człowieka do zjawisk zmysłowych, negujące częściowo lub całkowicie możliwość poznania obiektywnej rzeczywistości, a zwłaszcza możliwość poznania istoty rzeczy, natury związków przyczynowych i prawidłowości rozwojowych występujących w świecie.

Termin ten wprowadził w 1863 roku Thomas Henry Huxley, zasugerowany napisem Agnosto Theo, czyli „nieznanemu Bogu”, który

5 Por. Z. Zdybicka, Ateizm - zagrożeniem dla osoby, "Roczniki Filozoficzne” 19971998 z. 2, s. 51-68. 
według relacji św. Pawła miał znajdować się na jednym z ołtarzy w Atenach. Mianem tym Huxley określił stanowisko przeciwstawiające się zarówno teizmowi, jak i ateizmowi, a także tezie głoszącej materialność i poznawalność rzeczywistości. Później ta nazwa została rozciągnięta na wszystkie koncepcje filozoficzne stojące na stanowisku niepoznawalności świata lub pewnych jego aspektów. U Huxleya agnostycyzm miał jednak podstawy poznawcze, a zastosowanie tego pojęcia uzasadnia się także innymi motywami ${ }^{6}$.

Klasycznym przykładem zachodniego agnostycyzmu są poglądy sofisty Protagorasa z Abdery, który niepewność wiedzy o bogach uzasadniał nie tylko za pomocą racji poznawczych, lecz także odwołując się do argumentu krótkości życia.

Agnostycyzm odnajdujemy także w filozofii Wschodu. Według Buddy z kolei odpowiedź na metafizyczne problemy istnienia duszy, dalszego życia zbawionego po śmierci, jest niemożliwa z powodu niebezpieczeństwa zbłądzenia, przede wszystkim jednak z powodu braku znaczenia tych problemów dla zbawienia. Natomiast Konfucjusz odrzucił metafizyczne pytania, postulując konieczność koncentracji uwagi na życiu. Z racji różnych sposobów uzasadnienia pojęcie agnostycyzmu stosowane było nie tylko do określenia niemożliwości osiągnięcia transcendentnej wiedzy z powodów poznawczych, lecz także do usprawiedliwienia aktu odrzucenia takiej wiedzy.

Pojęcie agnostycyzmu ma w filozofii religii zarówno ogólne, jak i szczegółowe znaczenie. W tym pierwszym sensie odnosi się ono do każdej koncepcji, zgodnie z którą nasze poznanie istoty Boga podlega silnym ograniczeniom. W tej formie agnostycyzm podzielają filozofowie teiści i teologowie wszystkich wielkich religii. Twierdzenie, że natura Boga jest dla nas ukryta, znajduje się u Platona (Timajos), Plotyna (Enneady) i Tomasza z Akwinu (Suma teologiczna). Myśliciele

6 Agnostycyzm, w: Religia. Encyklopedia PWN, red. nauk. T. Gadacz, B. Milerski, t. 1, Warszawa 2001, s. 95. 
ci łączyli agnostycyzm z wiarą w Boga jako zasadą i początkiem wszystkiego, co istnieje; np. pierwsze znaczenie Boga według Tomasza z Akwinu polega na tym, że jest on źródłem wszystkiego, jest ponad wszystkim i od wszystkiego się różni. Tomasz był przekonany, że taka "zasada" i „początek” istnieją.

Nowych argumentów dostarczył agnostycyzmowi w XIV wieku nominalizm, zawężający zakres poznania do bytów jednostkowych i wykluczający poznawalność prawd metafizycznych i teologicznych. Przedstawicielem tego nurtu był Wilhelm Ockham. Uczniowie Ockhama (Jan z Mirecourt i Mikołaj z Autrecourt) dowodzili rozumowej niepoznawalności istnienia Boga. Tak rozumiany agnostycyzm stał się charakterystyczny także dla protestantyzmu. Według Martina Lutra rozum nie jest zdolny sam z siebie (bez pomocy wiary) poznać natury Boga, jest w stanie ją zaakceptować jedynie dzięki świadectwu Pisma Świętego (sola scriptura).

Pod koniec XIX wieku pojęciu agnostycyzmu nadano inne specyficzne znaczenie: agnostycyzm jako zasada poznawcza został umieszczony między teizmem i ateizmem i określony jako stan niemożliwości filozoficznego stwierdzenia istnienia bądź nieistnienia Boga. Takie właśnie rozumienie agnostycyzmu podzielał Huxley, a wraz z nim także inni myśliciele XIX i XX wieku (m.in. Herbert Spencer, Leslie Stephen, Bertrand Russel, Rudolf Otto, Hans Vaihinger). Do rozwoju tak rozumianego pojęcia przyczynili się David Hume, przeczący możliwości osiągnięcia wiedzy wykraczającej poza fakty, i Immanuel Kant, który doszedł do wniosku, że z punktu widzenia poznania Boga są one warunkami niemożliwości poznania. Do nauki Kanta nawiązał m.in. William Hamilton, który stwierdził, że człowiek poznaje jedynie zjawiska, a nie rzeczy.

Pojęcie agnostycyzmu zostało przeniesione także na grunt teologii - Wincenty Granat wprowadził tu termin „agnostycyzm teologiczny". Jest to stanowisko stwierdzające całkowitą niezdolność rozumu do poznania natury Boga, a w sensie pozytywnym ograniczające się 
do interpretacji prawd objawionych jedynie do tego, co Bóg sam o sobie objawił. Tak rozumiany agnostycyzm można odnaleźć m.in. u Pseudo-Dionizego Areopagity, którego poglądy wpłynęły na Jana z Damaszku, Bernarda z Clairvaux, Mistrza Eckharta. Głosił go także Majmonides, według którego w ziemskim życiu nie poznamy natury Boga.

Natomiast Karl Barth twierdził, że Boga poznajemy tylko przez niego samego. Z kolei według Rudolfa Bultmanna nie istnieje żadne inne poznanie Boga poza wiarą jako odpowiedzią człowieka na Ewangelię. Według W. Granata agnostycyzm występuje także u niektórych teologów współczesnych: m.in. Henriego de Lubaca. Agnostycyzm opiera się jego zdaniem na błędnych poglądach metafizycznych i na niewłaściwym rozumieniu poznania wywodzącego się z wiary. Kościół katolicki, stając w obronie obiektywności dogmatów, odrzucił agnostycyzm (encykliki Pascendi dominici gregis Piusa X z 1907 roku i Humani generis Piusa XII z 1950 roku).

Sobór Watykański II potwierdził naukę Soboru Watykańskiego I o możliwości poznania Boga za pomocą rozumu naturalnego. Natomiast w Katechizmie Kościoła katolickiego stwierdzono, że agnostycyzm może przybierać wiele postaci. Agnostyk może nie negować istnienia Boga i jednocześnie twierdzić, że nie jest ono możliwe do udowodnienia. Agnostycyzm może łączyć się z poszukiwaniem Boga, ale także obojętnością, praktyczną ucieczką przed ostatecznymi pytaniami. Dopiero w tym ostatnim znaczeniu staje się on ateizmem praktycznym.

Ateizm (z gr. $a$ - zaprzeczenie; theos - Bóg) to pogląd zaprzeczający istnieniu Boga lub jakiejkolwiek realnej więzi miedzy Nim a człowiekiem. Pogląd ten może przyjmować różne formy. Analizuje je Sobór Watykański II w Konstytucji duszpasterskiej o Kościele w świecie współczesnym Gaudium et spes ${ }^{7}$. Stwierdza mianowicie, że ateizm

7 Por. Sobór Watykański II, Konstytucja duszpasterska o Kościele w świecie współczesnym Gaudium et spes [dalej: KDK], 19, 20. 
może oznaczać takie zjawiska jak: wyraźne zaprzeczenie istnieniu Boga, zwątpienie w możliwość dojścia do pewności w Jego poznaniu, uznanie problematyki Boga za bezsensowną, ograniczenie całej wiedzy ludzkiej do nauk pozytywnych, odrzucanie istnienia prawd absolutnych, absolutyzowanie człowieka i dóbr doczesnych, tworzenie niewłaściwych pojęć o Bogu, namiętny protest przeciw złu, zanik religijnego niepokoju.

Ateizm współczesny przejawia się zarówno w praktyce, jak i w teorii. Ateizm praktyczny łączy się często z rozwojem współczesnej cywilizacji, ukierunkowanej materialistycznie. Jako teoria głosi on absolutną autonomię człowieka: jednostka ma być sam sobie celem i jedynym sprawcą swojej historii. Wiąże się z tym przekonanie, że pełną wolność człowiek może osiągnąć przez wyzwolenie gospodarcze i społeczne, a nie przez zbawienie pochodzące od Boga. Te ateistyczne doktryny opierają się na poglądach głoszonych przez klasyków marksizmu, a także Friedricha Nietzschego, Sigmunda Freuda i Jeana-Paule’a Sartre’a. Ateistyczne konsekwencje wynikają też ze strukturalizmu głoszonego przez Claude’a Lévi-Straussa i ze scjentyzmu wyznawanego przez neopozytywistów i niektórych przedstawicieli filozofii analitycznej (np. B. Russella).

Chociaż ateizm występuje obecnie w wielu krajach jako zjawisko masowe, nie jest on ściśle związany ze współczesnym postępem nauki i kultury. Na pewne formy ateizmu natrafiamy we wszystkich niemal epokach. Źródła ateizmu bywają rozmaite. Mogą to być przyczyny społeczne, jak sposób wychowania, środowisko, a także rozmaite przyczyny indywidualne - czy to intelektualne, jak zbyt wąska specjalizacja, szukanie łatwych uogólnień, postawa sceptycyzmu, różne uprzedzenia i nawyki myślowe lub emocjonalne, zwłaszcza przeżywanie cierpienia i zła, czy to moralne, to znaczy postępowanie niezgodne ze sumieniem dla jakichś doraźnych korzyści.

Ateizm nie zawsze jest zawiniony i wynika ze złej woli. Dlatego Sobór Watykański II nie potępia ateizmu, ale nad nim boleje, stara się 
poznać jego źródła i wskazać sposoby jego przezwyciężenia ${ }^{8}$. Sobór nie wyklucza nawet możliwości zbawienia tych, „którzy bez własnej winy nie doszli jeszcze do wyraźnego poznania Boga, ale usiłują, nie bez łaski Bożej, wieść życie uczciwe" ${ }^{9}$, uznają podstawowe zasady moralne i starają się zgodnie z nimi prowadzić swe życie. Mówiąc o katolickiej postawie wobec niewierzących ${ }^{10}$, Sobór przestrzega, aby w nauczaniu i postępowaniu unikać tego wszystkiego, co zaciemnia i zniekształca prawdziwy obraz Boga i czystą treść Chrystusowej Ewangelii, unikać różnych przesądów, zbędnych antropomorfizmów, a zwłaszcza postawy zakłamania. Napomina też, by zarówno nauczaniem, jak i przede wszystkim świadectwem świętego życia wykazywać wartość wiary w Boga i wartość religii dla prawdziwej godności ludzkiej, dla sprawiedliwości i miłości społecznej już tu, na ziemi, a zwłaszcza dla odpowiedniego rozwiązania ostatecznych zagadnień losu ludzkiego, odnalezienia sensu życia i szczęścia.

Chociaż Kościół odrzuca doktrynę ateizmu i przeciwstawia się naruszaniu wolności religii, pragnie prowadzić dialog z niewierzącymi i współpracę w celu odnowienia stosunków społecznych w duchu prawdy, sprawiedliwości i miłości, a także by dawać ewangeliczne świadectwo wszystkim ludziom. Papież Paweł VI ustanowił 9 czerwca 1965 roku Sekretariat do spraw Niewierzących, przekształcony później w papieską Radę do spraw Dialogu z Niewierzącymi ${ }^{11}$.

Paweł VI w encyklice Ecclesiam suam (1964) wylicza trzy kategorie ateistów:

- Pierwsza grupa to ci, „którzy nie wyznają żadnej religii”, ludzie indyferentni, agnostycy, a także ci, którzy nie wyznają wiary w Boga; religia jest dla nich sprawą obojętną, nie przywiązują

\footnotetext{
8 Por. KDK 19-21.

9 Sobór Watykański II, Konstytucja dogmatyczna o Kościele Lumen gentium, 16.

10 Por. KDK 19-21.

11 Ateizm, w: Słownik teologiczny, pod red. A. Zuberbiera, Katowice 1998, s. 48-49.
} 
do niej żadnej wagi, nie starają się z nią nawet walczyć, żyją więc poza nią. Ateizm tej grupy należy określić jako praktyczny ${ }^{12}$.

- Do drugiej grupy papież zalicza tych, którzy jawnie deklarują się jako ateiści: wielu $\mathrm{z}$ różnych przyczyn zaprzecza istnieniu Boga. Wiadomo, że wśród duża ich część jawnie okazuje swą bezbożność i walczy, by wprowadzić jej zasady w instytucje wychowawcze i życie publiczne. Doszła bowiem do niedorzecznego i szkodliwego przekonania, że uwalnia ludzi od przestarzałych i fałszywych poglądów o życiu i świecie, dając w zamian, jak twierdzi, poglądy zgodne z nauką i postępem. Ta grupa ludzi rozszerza wyznawany przez siebie pogląd na książki i inne publikacje, środki masowego przekazu. Jest to ateizm poparty odpowiednią filozofią. W tej grupie można umieścić ateizm doktrynalny, filozoficzny i marksistowski ${ }^{13}$.

- Trzecia kategoria ateistów według Pawła VI to komuniści: oddaleni od Kościoła, nieugięci w przekonaniach i stwarzający szczególny problem nie tylko dla katolików, lecz także dla całej ludzkości. Zagrożenia wynikające $z$ tego typu ateizmu potęguje fakt, że jeszcze dziś jest on lansowany i popierany przez państwa, dla których stanowi podwalinę ideologiczną ${ }^{14}$.

Teologowie i filozofowie zajmujący się ateizmem dokonują specyficznego kryterium podziału:

- Wincenty Granat jako kryterium podziału przyjmuje źródła, z których wywodzi się ateizm, formę, jaką przybiera, i cele, jakie mu przyświecają. W związku z tym wyróżnia: ateizm teoretyczny i praktyczny, pozytywny i negatywny, absolutny i względny, epistemologiczny i ontologiczny, przyrodniczy i antropologicz-

12 Ateizm, w: Leksykon teologii fundamentalnej, red. M. Rusiecki i in., Lublin-Kraków 2002, s. 125.

13 Ateizm, w: Leksykon teologii fundamentalnej, dz. cyt., s. 125.

14 Ateizm, w: Leksykon teologii fundamentalnej, dz. cyt., s. 125. 
ny, intelektualny i wolitywny, emocjonalny i pragmatyczny, integralny i cząstkowy ${ }^{15}$.

- Walter Kasper jako kryterium podziału przyjmuje stosunek człowieka do natury, kultury, nauki, sztuki, gospodarki i polityki. Rozróżnia ateizm naturalistyczny, materialistyczny, scjentystyczny, metodyczny i agnostyczny. Jako drugie kryterium podziału przyjmuje autonomię podmiotu i według niego rozróżnia humanistyczny ateizm wolności i polityczny ateizm wyzwolenia.

- Karl Rahner jako kryterium podziału przyjmuje źródła pochodzenia ateizmu - mówi o ateizmie naiwnym i powierzchownym (do którego zalicza ateizm z przełomu XVIII i XIX wieku, którego zwolennicy twierdzili, że Boga nie ma), ateizmie zasmuconym lub zatroskanym (który charakteryzuje taki stan przerażenia nieobecnością Boga w świecie i Jego milczeniem, że człowiek nie może już realizować w żaden sposób tego, co boskie w świecie, i z przerażeniem stwierdza, że świat jest pusty i bezsensowny) oraz ateizm indyferentny (charakteryzujący się zupełną obojętnością wobec problemów religijnych) ${ }^{16}$. Dzidek i Kościelniak wyróżniają cztery zasadnicze formy współczesnego ateizmu:

- Ateizm naturalistyczny opiera się na metodzie nauk pozytywnych, przyjmuje tylko rzeczywistość złożoną z elementów fizyczno-chemicznych i biologicznych; redukuje wszystko także człowieka - do pewnych struktur i praw. W ateizmie naturalistycznym zawiera się ateizm marksistowski: Karol Marks odrzucił istnienie Boga zgodnie ze swoimnaturalistycznym humanizmem. Postrzegając religię jako formę duchowej alie- 
nacji człowieka, uznał ją za coś wtórnego względem modelu gospodarczo-społecznego.

- Ateizm nepozytywistyczny związany jest z Kołem Wiedeńskim i koncepcjami Moritza Schlicka i Rudolfa Carnapa. Podzielili oni zdania na sensowne, czyli takie, których prawdziwość da się wykazać, oraz fałszywe, czyli te, których prawdziwości nie da się wykazać. Do tych drugich, nazywanych także bezsensownymi lub metafizycznymi, zaliczyli stwierdzenie o istnieniu Boga. Neopozytywizm nie głosi ani że Bóg istnieje, ani też że Bóg nie istnieje, a Jego afirmacja lub negacja pozbawione są sensu.

- Ateizm antropologiczny związany jest z egzystencjalizmem, który w wielu odmianach koncentruje się na pojęciu wolności jako kondycji człowieka. Sartre był tu mistrzem jako autor znanej sentencji - „gdyby Bóg istniał, należałoby go odrzucić”.

- Ateizm praktyczny charakteryzuje ludzi, którzy nie są ateistami, nie wywodzą się z kręgów intelektualnych, nie negują Boga, ale żyją tak, jakby Go nie było, posiadają jakąs ideę Boga, który istnieje, ale który jednocześnie jest nieobecny w ich życiu. Przyczynami takiego ateizmu są: nadmierny dobrobyt, antyświadectwo wierzących, ukazywanie chrześcijaństwa zgorzkniałego, instytucjonalnego, uwikłanego $\mathrm{w}$ walkę polityczną i ekonomiczną, skupianie na grzechu, kult ciała i sportu, rozbicie jedności między miłością a erotyką, środki masowego przekazu, przemysł rozrywkowy pochłaniający człowieka do tego stopnia, że zabija w nim refleksję nad sensownością życia ${ }^{17}$. Pojęciem nawiązującym do ateizmu jest laicyzacja. W szerokim znaczeniu termin ten używany jest na określenie ludzkich postaw niezależnych od religii lub na oznaczenie przemian społeczno-kulturowych w nowoczesnych lub ponowoczesnych społeczeństwach, niosących ze sobą emancypację oraz wyzwolenie spod wpływów

17 Ateizm, w: Leksykon teologii fundamentalnej, dz. cyt., s. 129. 
instytucji kościelnych i religijnych w różnych dziedzinach i obszarach życia społecznego ${ }^{18}$.

Laicyzacja oznacza także zjawisko zmniejszania się i zanikania wpływu wartości religijnych na indywidualne i społeczne życie ludzi, aż po utratę znaczenia przez religijne systemy interpretacji sensu życia. Rozumiana jest jako program działania państwa lub różnych instytucji politycznych głoszących konieczność podjęcia akcji zmierzających do uwolnienia spod wpływów Kościoła życia publicznego oraz nadania mu politycznie pożądanych kształtów (np. przesunięcie Kościoła na margines nowego porządku społecznego stworzonego przez władze komunistyczne).

Jako świadomy program budowy życia społecznego i kultury bez religii laicyzacja jest sprzeczna $z$ chrześcijańską wizją świata. Rozumiana jako walka z religią i Kościołem przy użyciu siły i przemocy, jest też niezgodna z zasadą tolerancji religijnej. Wspólnym mianownikiem współczesnych nurtów laicyzujących jest traktowanie religii jako sprawy ściśle prywatnej i pozbawienie jej wszelkiego realnego wpływu na życie społeczne ${ }^{19}$.

Według Władysława Piwowarskiego znaczenie terminu „laicyzacja” nie jest dostatecznie sprecyzowane. Na ogół używa się go jako określenia procesów przemian kulturowo-społecznych dokonujących się w czasach nowożytnych i współczesnych, w wyniku których różne dziedziny życia, jak polityka, nauka, filozofia, kultura, oświata i wychowanie, stopniowo stają się niezależne od instytucji kościelnych i religijnych. W ujęciu radykalnym laicyzacja to proces, w którym religijne myślenie, praktyki i instytucje tracą swoje społeczne znaczenie. Na określenie tego procesu w społeczeństwach zachodnich używa się terminu „sekularyzacja”, w Polsce zaś „laicyzacja” 20 .

18 Ateizm, w: Leksykon teologii fundamentalnej, dz. cyt., s. 747.

19 Ateizm, w: Leksykon teologii fundamentalnej, dz. cyt., s. 748.

20 Ateizm, w: Leksykon teologii fundamentalnej, dz. cyt., s. 749. 
Znawcy tej problematyki wyróżniają dwie formy laicyzacji:

- Laicyzacja spontaniczna jest procesem wyzwalania się instytucji społecznych lub indywidualnej i zbiorowej świadomości spod wpływów Kościoła. Oznacza oddzielenie sacrum od profanum, religia nie determinuje już życia codziennego, które poddane jest logice wartości doczesnych. Taka forma laicyzacji prowadzi do postaw indyferentnych wobec wszelkiej transcendencji, aż po postawy ateistyczne. Związana jest z życiem makrostrukturalnym (np. industralizacją, urbanizacją, techniką, rozwojem oświaty). Niektórzy próbują nawet nazwać ją sekularyzacją i odnoszą do wszelkich procesów zeświecczenia jednostki i społeczeństwa ${ }^{21}$.

- Laicyzacja sterowana jest procesem zaplanowanym, odgórnym, zamierzonym politycznie; często wiąże się z ideologią laicyzmu, odrzucającego rzeczywistość transcendentną. W praktyce oznacza rozdział Kościoła od państwa, laickie ustawodawstwo i oświatę, kontrolowanie przez państwo działalności charytatywnej prowadzonej przez Kościól, traktowanie religii jako sprawy wyłącznie prywatnej.

Skutkiem laicyzacji jest proces desakralizacji tj. osłabienie, a nawet zanik więzi wyznaniowych, zmniejszenie się stopnia i zasięgu uczestnictwa w praktykach religijnych, zmniejszenie autorytetu duchowieństwa, spadek powołań kapłańskich, nadawanie świeckiego charakteru przełomowym momentom w życiu człowieka (pogrzeby świeckie, śluby cywilne). Desakralizacja prowadzi do wyeliminowania sacrum - to obumieranie religii wierzeń, to kształtowanie się orientacji o charakterze ateistycznym ${ }^{22}$.

Zeświecczenie następowało w średniowieczu (oddzielenie papiestwa od cesarstwa), w XVII i XVII wieku (rewolucja naukowa 
w Europie, sekularyzacja nauki i kultu, rewolucja francuska w 1789 roku zmierzająca do ograniczenia wpływów Kościoła i wyeliminowania religii z życia społecznego). W XVII wieku z woli władzy tworzono laicką szkołę, moralność, oddzielenie Kościoła od społeczeństwa, państwo neutralne światopoglądów, całkiem laickie ${ }^{23}$.

Laicyzacja jako proces społeczny stanowi ważny problem dla Kościoła, ale oprócz negatywnych konsekwencji może nieść także skutki pozytywne, które przyczyniają się do swoistego oczyszczenia religii z elementów magicznych i do koncentracji Kościołów na ich istotnej misji ewangelizacyjnej. Kościoły w warunkach laicyzacji tracą swoje role polityczne i kulturowe, pogłębiają natomiast swoje funkcje etyczno-religijne ${ }^{24}$.

Innym pojęciem, który nawiązuje jednak do laicyzacji, jest wspomniana już sekularyzacja. Pochodzi od łacińskiego saecularis (łączącego się z następującymi terminami: „świecki”, „zeświecczenie”, „laicyzacja”, ,emancypacja”, „dechrystianizacja”, „desakralizacja”, „odkościelnienie”, „niereligijność”, „odmitologizowanie”, „dekonfesjonalizacja”). Był to termin rzucony jako wyzwanie chrześcijaństwu w XIX wieku. W szerokim znaczeniu określał zjawisko rozluźnienia więzi z Kościołem, z religią, odejście od zinstytucjonalizowanych form pobożności, jak również uwolnienie spod władzy Kościoła i odbieranie mu dóbr ${ }^{25}$.

W teologii sekularyzacja oznacza autonomię człowieka w sprawach doczesnych, zapewnienie rzeczom stworzonym właściwych im praw i wartości, które człowiek powinien poznawać, przyjmować i porządkować ${ }^{26}$. Uzasadniony proces samowyzwalania, zgodny z nauką o stworzeniu i podporządkowaniu sobie świata przez człowieka $(\mathrm{Rdz} 1,28)$ może przekształcić się w sekularyzm, czyli doktrynę

23 Ateizm, w: Leksykon teologii fundamentalnej, dz. cyt., s. 749.

24 Ateizm, w: Leksykon teologii fundamentalnej, dz. cyt., s. 750.

25 Ateizm, w: Leksykon teologii fundamentalnej, dz. cyt., s. 1089.

26 KDK 36. 
przeceniającą możliwości poznawcze człowieka, prowadzącą do pomijania Boga w działaniach człowieka, a nawet do zaprzeczenia Jego istnienia, czego konsekwencją jest ateizm ${ }^{27}$.

Wszystkie te cechy wskazują, że sekularyzacja znajduje swoje miejsce między religią a ateizmem, a w konsekwencji między problemem wiary i niewiary. Tendencje sekularystyczne są zakorzenione w każdej religii, a chrześcijaństwo jest uznawane za ich prekursora. W adhortacji Pawła VI Evangelii nuntiandi sekularyzacja jest uznawana za słuszne i prawowite, nieobce wierze i religii usiłowanie odkrycia autonomii w każdej rzeczy. Sobór potwierdził uprawnioną autonomię kultury ludzkiej, a zwłaszcza nauki ${ }^{28}$.

Sekularyzm stał się określonym programem światopoglądowym opierającym się z reguły na materialistycznej koncepcji człowieka i postulującym ateizację społeczeństwa. Wiąże się również z pewnym typem mentalności naukowo-technicznej, lansującym obraz świata bez Boga, kwestionującej nawet transcendentną wartość samego człowieczeństwa. Sekularyzm i związany z nim indyferentyzm stanowią zagrożenie dla religii, ale oznaczają one również obojętność a nawet wrogość wobec dziedzictwa chrześcijańskiego, negację Boga prowadzącą do negacji człowieka ${ }^{29}$.

Chrześcijanin nie powinien popadać w skrajności sekularyzmu powinien dawać wyraz swej nadziei również w obrębie struktur życia świeckiego. Kościół współczesny usiłuje na nowo wprowadzić wiarę w przestrzeń kultury naszych czasów i na nowo wcielać wartości chrześcijańskiego humanizmu. Przede wszystkim próbuje zaś przeciwdziałać niebezpiecznej i szkodliwej dychotomii, która oddziela wiarę od moralności ${ }^{30}$.

27 Ateizm, w: Leksykon teologii fundamentalnej, dz. cyt., s. 1090.

28 Ateizm, w: Leksykon teologii fundamentalnej, dz. cyt., s. 1090.

29 Ateizm, w: Leksykon teologii fundamentalnej, dz. cyt., s. 1091.

30 Ateizm, w: Leksykon teologii fundamentalnej, dz. cyt., s. 1092. 
Nawet agnostycy mogą być potrzebni Kościołowi - stwierdzono na sesji naukowej w Tarnowie. Spotkanie zatytułowane Między wiara i niewiara. Oblicza agnostycyzmu zorganizowali 14 kwietnia 2005 roku biskup tarnowski Wiktor Skworc i starosta powiatu tarnowskiego Michał Wojtkiewicz. Zaproszeni naukowcy, filozofowie i teologowie zastanawiali się m.in. nad tym, czy bycie agnostykiem stało się w dzisiejszych czasach modą. Grzegorz Wrochna z Instytutu Problemów Jądrowych w Świerku przyznał, że w swoim środowisku spotyka wielu naukowców-agnostyków. „Prezentują oni agnostycyzm praktyczny i najczęściej nigdy nie zadali sobie trudu zapoznania się z tym, co na temat Boga ma do powiedzenia chrześcijaństwo" 31 stwierdził Grzegorz Wrochna. Współczesny agnostycyzm nazwał on lenistwem duchowym. Jego zdaniem agnostycy nie znają bogactwa intelektualnego chrześcijaństwa, gdyż nie zadali sobie trudu zapoznania się z tym potencjałem. Z Grzegorzem Wrochną zgodził się prof. Aleksander Bobko z Uniwersytetu Rzeszowskiego, który stwierdził, że postęp techniki we współczesnym świecie pozwala nie myśleć na co dzień o wielu sprawach i nie stawiać trudnych pytań. „Żyjemy tak, jakby wszystko było w naszych rękach, a różne sprawy są do rozwiązania przez samego człowieka - stwierdził Bobko. - Gdy mamy kłopot, to dzwonimy do określonej firmy, która nam problem rozwiązuje. Natomiast o problemach «nie do załatwienia» próbujemy zapomnieć”. Jako przykład Bobko podał śmierć, od dawna istotny i wciąż obecny motyw kulturowy. Wykładowca dodał jednak, że śmierć Jana Pawła II pokazała, że istnieją takie sytuacje, w których z zapomnianymi i odpychanymi problemami człowiek musi się zmierzyć. „I tutaj oferta religii, a chrześcijaństwa w szczególności, jest niezwykle atrakcyjna” - stwierdził. Atrakcyjność ateizmu i agnostycyzmu próbował przedstawić prof. Piotr Gutowski z Katolickiego Uniwersytetu

31 Ten i kolejne cytaty w tej części artykułu pochodzą z referatów wygłoszonych podczas spotkania Między wiarq i niewiara. Oblicza agnostycyzmu (14.04.2005). 
Lubelskiego. W wykładzie zatytułowanym Bóg a zło naturalne mówił m.in. o współczesnych cierpieniach powodowanych przez różne kataklizmy, np. tsunami. Podkreślił, że ze złem naturalnym w różnych postaciach mamy do czynienia w codziennym życiu. Wykorzystują to agnostycy i ateiści, tłumacząc, że jeśli Bóg istnieje, to albo nie opiekuje się światem, albo nie jest dobry, wszechmocny i wszechwiedzący. Profesor Gutowski stwierdził, że dzięki agnostykom teologowie napotykają na kolejne wyzwania. „Byłoby nawet niedobrze, gdyby takich ludzi [agnostyków] zabrakło" - dodał. Jako przykład podał kraje islamu, w których nie ma poszukujących i stawiających pytania wyznawców tej religii. Gutowski jest przekonany, że chrześcijaństwo ma ogromne możliwości intelektualne ze względu na bogatą teologię i filozofię. „Nawet dziś chrześcijaństwo może być atrakcyjne nawet dla bardzo krytycznych umysłów" - stwierdził.

Przed ludźmi świata nauki stoją wyzwania, aby ukazać poszanowanie wolności ludzkiej, nie naruszając prawdy o transcendentalnej godności osoby ludzkiej - ale czekają też wielkie możliwości intelektualne i bogata terminologia, które mogą pomóc w osiągnięciu tego celu ${ }^{32}$. 